\begin{tabular}{l|c|c}
\hline ISSN: 0001-5113 & ACTA ADRIAT., & ORIGINAL SCIENTIFIC PAPER \\
AADRAY & $58(1): 157-164,2017$ & \\
\hline
\end{tabular}

\title{
A long term (1949-2010) study of catch and effort in Israeli trawl fishery, Eastern Mediterranean Sea
}

\author{
Daniel GOLANI ${ }^{1 *}$, Dor EDELIST ${ }^{2}$, Amit LERNER $^{3}$, Oren SONIN ${ }^{4}$ \\ and Uzi MOTRO ${ }^{1}$ \\ ${ }^{1}$ Department of Ecology, Evolution and Behavior, The Hebrew University of Jerusalem, 91904 \\ Jerusalem, Israel \\ ${ }^{2}$ Department of Maritime Civilizations, Haifa University, Haifa 31905, Israel \\ ${ }^{3}$ Hanesher 18A, Binyamina 30500, Israel \\ ${ }^{4}$ Department of Fisheries, Ministry of Agriculture, P.O.B. 1213, Kiryat Haim 26105, Israel \\ *Corresponding author: dani.golani@mail.huji.ac.il
}

The trawl fishery of the Mediterranean coast of Israel was analyzed vis á vis catch and fishing effort for the years 1949-2010. The Maximum Sustainable Yield (MSY) was calculated using the Fox surplus-yield model and was found to be 1,413 ton per annum using 1,415 units of effort (fishing days X engine power divided by 1000). Only during nine years (1997-2005) did fishing effort exceed the value for which the yield is the MSY by an average of 184.9 units of effort, but the yield was similar to that of the previous years. During 10 years the catch exceeded the MSY by an average of $153 \pm 119$ tons. This result was used to justify the "freezing" of the local trawl fleet at the beginning of the 1990's.

Key words: Trawl, Israel, Mediterranean, Maximum Sustainable Yield, Fox model

\section{INTRODUCTION}

The Mediterranean commercial fishery of Israel can be divided into three main components: artisanal fishery, purse seine and trawl, with an annual catch of ca. 3,000 tons. The fourth component is non-commercial or recreational fishery of unknown scope. Recently, the question of the impact of Israeli fisheries on the marine ecosystem has become a central issue in the public sphere. In this public discussion, trawl fishing has been labeled as the main factor causing the alleged deterioration of the ecosystem, loss of biodiversity and consequently, a decline in the total catch. Therefore, the purpose of this study is to check if the Israeli trawl fishing exceeded its MSY by present long-term documented data.

\section{History of Israeli trawl fishing}

Trawl fishing in Israel began in the 1930's with several small Italian boats that trained local fishermen. However, the extent of this fishery and catch was not documented (HORNELL, 1935). The documentation of local trawl activity began with the establishment of the State of Israel in 1948. 
Until the end of the 1970's, the Israeli trawl fleet consisted of 30 small to medium-sized boats with engines of 100-200 HP (most boats with 120-170 HP). Trawl nets had a low vertical height of $80-100 \mathrm{~cm}$ and horizontal opening of 10-15 m and sweeps of 70-200 m leading to otter boards, typically spaced $50-80 \mathrm{~m}$ when dragged on the seabed. Towards the end of the 1970's, several high opening trawl nets with vertical opening of $2.5 \mathrm{~m}$ were introduced. This enabled catching semi-pelagic species as well. At that time, some boats had their engines replaced by $150-240 \mathrm{HP}$.

A dramatic increase in demand for shrimps, during 1983-1984 led to the introduction of 7 or 8 new smaller sized shrimpers to the local fleet, increasing its size by $35-40 \%$. The shrimp trawls had a low opening net of similar horizontal opening to the traditional trawlers (10-15 m) and were equipped with a "ticker chain" burrowing in the sea floor, $0.5-1.0 \mathrm{~m}$ in front of the ground rope. The shrimpers operated without sweeps, using smaller engines of 120-210 HP (most used 120-180 HP). At the same time, several traditional trawlers installed "dual-purpose trawl nets". This type, developed in Israel, had larger wings enabling the vertical opening to reach $2 \mathrm{~m}$ and allowed catching both shrimps and demersal and semi-pelagic fish. During this period, some boats upgraded their engines up to $400 \mathrm{HP}$.

The entire Israeli trawl fleet used nets with diamond mesh of 36-48 mm (most of 40-44 mm) starched mesh cod end. This gear did not change significantly throughout the years (GOTTLIEB \& OREN, 1957; GROFIT, 1980; EDELIST et al., 2011).

\section{MATERIAL AND METHODS}

\section{Catch and Fishing effort}

The data on fishing effort and catch were obtained from the annual reports of the Fishery Department of the Israeli Ministry of Agriculture (Fishery Department, 1950-2007). In these reports, the total catch (in tons) was given, as well as the number of fishing days and engine size (in HP) of each trawler. During the years 2008-2010, this information was obtained from surveys conducted by the Fishery Department (SCHEININ, 2010; EDELIST, 2013). The annual fishing effort was calculated as the sum of the fishing days times the total sum of Horse Power (HP).

Since the annual reports did not provide detailed data of the proportions of activity in the use of each trawl type, we combined, in this study, the annual catch against the entire fishing effort.

\section{Data analysis}

We estimated the Maximum Sustainable Yield (MSY) by fitting the data to the Surplus Yield Model of Fox (FOX, 1970):

$$
y=f e^{(a+b f)}
$$

where: $y$ is the catch , $f$ is the fishing effort, $a$ and $b(b<0)$ are parameters. We measured catch in tons and fishing effort by the sum (over the entire participating fleet) of horse power multiplied by fishing days for each vessel, divided by 1000 (HP x days x 10 10, henceforth units of effort).

The years 1954-1959 were excluded from all calculations; in those years some Israeli trawlers fished in the much richer fishing grounds of Turkey. Trawlers traveled for two days, fished for two days and returned to Israel for another two days. However, in the official reports, only two days of fishing effort were recorded. Since we have no knowledge of the proportion of the activity in Turkey out of the entire Israeli trawl fishing activity, we excluded these years. Israeli trawl fishing along the Turkish coast ceased after 1959. In order to assess whether there was a trend of catch/fishing effort after the introduction of the shrimpers to the Israeli trawl fleet in 1983-1984, we divided this period into two parts:1985-1997 and 1998-2010 and we applied the Fox model on each period, separately.

\section{RESULTS}

Table 1. and Fig. 1. present the annual catch and the fishing effort of the Mediterranean Israeli trawl fleet for the years 1949-2010.

Using a regression model, and excluding the years 1954-1959 (thus $n=56$ ), we found 
Table 1. Catch (in tons) and fishing effort (in $H P \times d a y s \times 10^{-3}$ ) of the Israeli Mediterranean trawl fishing activity during the years 1949-2010

\begin{tabular}{cccccc}
\hline Year & $\begin{array}{c}\text { Total } \\
\text { Catch }\end{array}$ & $\begin{array}{c}\text { Fishing } \\
\text { Effort }\end{array}$ & Year & $\begin{array}{c}\text { Total } \\
\text { Catch }\end{array}$ & $\begin{array}{c}\text { Fishing } \\
\text { Effort }\end{array}$ \\
\hline 1949 & 646 & 182 & 1980 & 892 & 621 \\
1950 & 1092 & 434 & 1981 & 907 & 651 \\
1951 & 929 & 361 & 1982 & 835 & 613 \\
1952 & 1000 & 344 & 1983 & 980 & 657 \\
1953 & 1286 & 495 & 1984 & 1283 & 899 \\
1954 & 1480 & 487 & 1985 & 1215 & 688 \\
1955 & 1518 & 615 & 1986 & 1392 & 119 \\
1956 & 1391 & 531 & 1987 & 1408 & 1160 \\
1957 & 1550 & 625 & 1988 & 1590 & 1220 \\
1958 & 1809 & 740 & 1989 & 1655 & 1213 \\
1959 & 2010 & 810 & 1990 & 1757 & 1330 \\
1960 & 1274 & 561 & 1991 & 1455 & 1206 \\
1961 & 992 & 489 & 1992 & 1328 & 1218 \\
1962 & 830 & 443 & 1993 & 1397 & 1202 \\
1963 & 707 & 398 & 1994 & 1107 & 1172 \\
1964 & 615 & 323 & 1995 & 1336 & 1343 \\
1965 & 761 & 398 & 1996 & 1196 & 1384 \\
1966 & 638 & 413 & 1997 & 1316 & 1509 \\
1967 & 741 & 434 & 1998 & 1409 & 1597 \\
1968 & 926 & 426 & 1999 & 1530 & 1671 \\
1969 & 1028 & 451 & 2000 & 1470 & 1650 \\
1970 & 931 & 479 & 2001 & 1735 & 1628 \\
1971 & 1174 & 471 & 2002 & 1588 & 1605 \\
1972 & 1202 & 528 & 2003 & 1397 & 1580 \\
1973 & 1136 & 590 & 2004 & 1061 & 1554 \\
1974 & 934 & 554 & 2005 & 1320 & 1507 \\
1975 & 925 & 560 & 2006 & 1200 & 1253 \\
1976 & 1082 & 607 & 2007 & 1454 & 1349 \\
1977 & 964 & 598 & 2008 & 1227 & 1309 \\
1978 & 1055 & 719 & 2009 & 1348 & 1269 \\
1979 & 966 & 642 & 2010 & 1429 & 1293 \\
\hline & & & & &
\end{tabular}

Fig. 1. Total trawl fishing effort (in $H P \times$ days $\times 10^{-3}$ ) and total catch (in tons) for the Mediterranean fishery of the Israeli trawl fleet over the years 1949-2010. (Each decade is designated by a different color)
Trawl Fishing Effort and Total Catch (1949-2010)

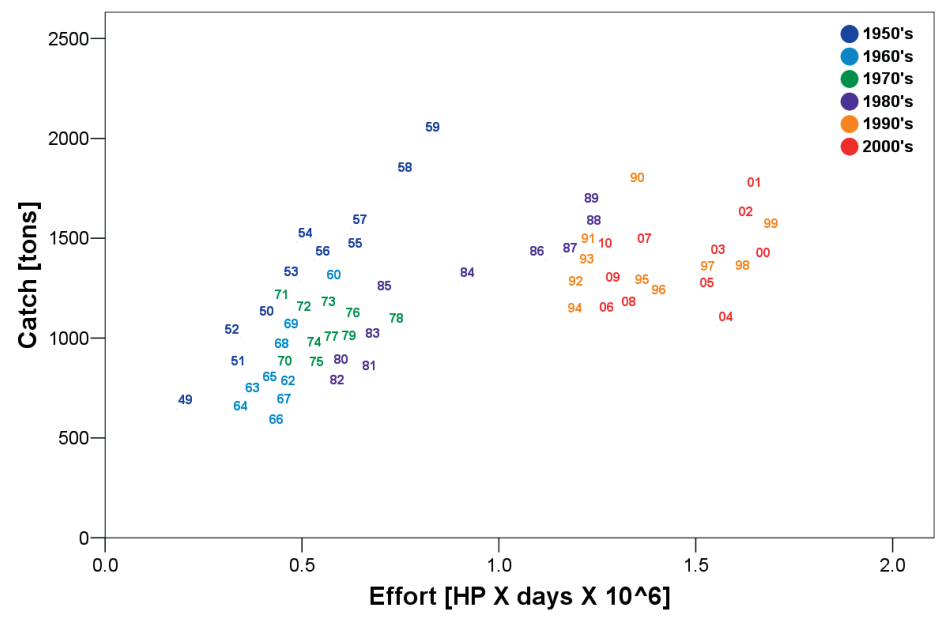




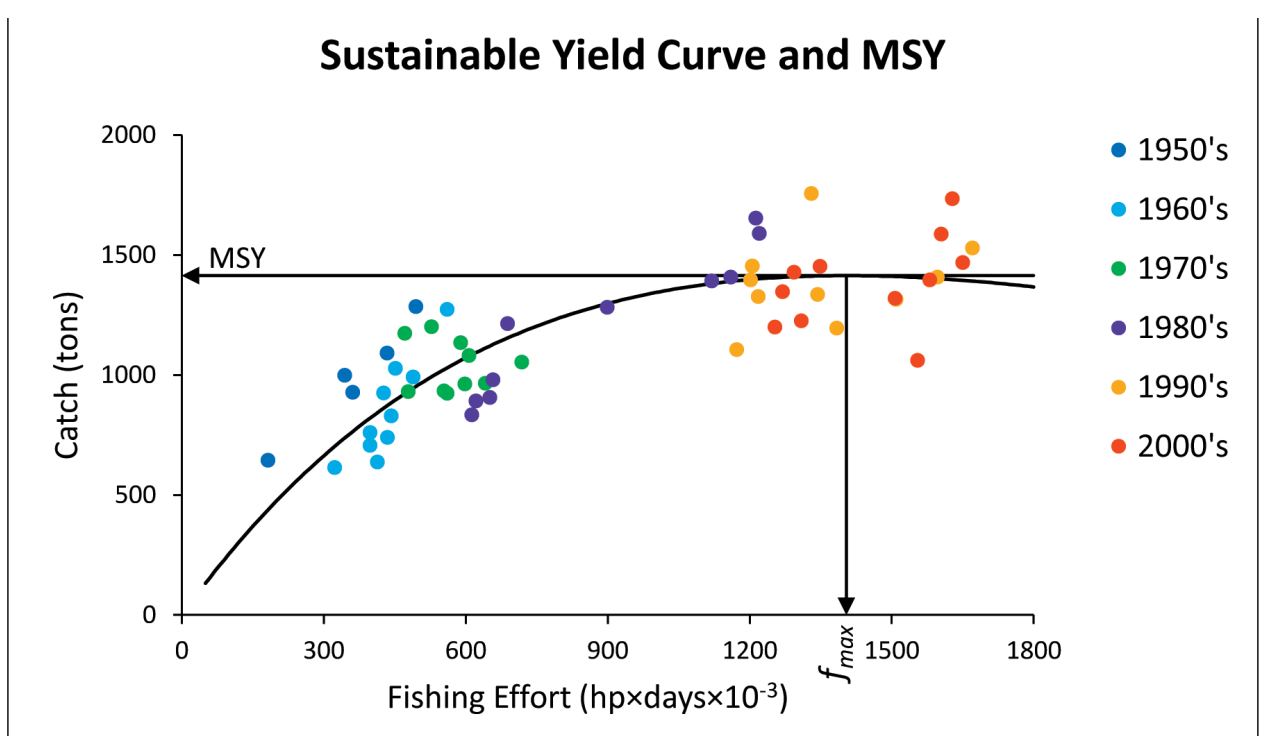

Fig. 2. Surplus yield curve and MSY for the catch of the Mediterranean trawl fishery of Israel for the years 1949-2010

Table 2. Comparing the mean fishing effort (in $H P \times$ days $\times 10^{-3}$ ) and the mean total catch (in tons) between the years 1984-1996 and 1997-2010. All p-values are for a two-tailed alternative.

\begin{tabular}{lllll}
\hline & Fishing Effort & \multicolumn{3}{l}{ Catch } \\
\hline Years & $1984-1996$ & $1997-2010$ & $1984-1996$ & $1997-2010$ \\
$n$ & 13 & 14 & 13 & 14 \\
mean \pm se & $1165.7 \pm 51.8$ & $1483.9 \pm 41.3$ & $1393.8 \pm 51.6$ & $1391.7 \pm 45.3$ \\
$t$-test & $t_{25}=4.836 p=5.7 \times 10^{-5}$ & $t_{25}=-0.030 p=0.976$ \\
\hline
\end{tabular}

for the surplus yield curve: $\hat{a}=1.007 \pm 0.052$ and $\hat{b}=(-7.122 \pm 0.454) \times 10^{-4}$ (estimates \pm se), with $R^{2}=0.648$. The estimated MSY is $1414.0 \pm 34.7$ tons, obtained for an effort of $f_{\max }=1404.1 \pm 89.5$ units (see Fig. 2).

Only during nine consecutive years (1997$2005)$, the yearly fishing effort exceeded $f_{\max }$ , the effort for which the yield is the MSY. The average excess was 184.9 units of effort, slightly more than two standard errors above $f_{\max }$. The fishing effort decreased below that level afterwards (2006-2010), from a mean of 1589 units during $1997-2005$ to 1295 units during the last five years of our study (Fig. 3, $\left.t_{12}=10.214 p<10^{-6}\right)$.

During ten years (out of the 56 years analyzed), the yield exceeded the MSY. The average excess during these years was 152.3 tons.

Comparing between the mean fishing effort and the mean total catch during the years 1984-

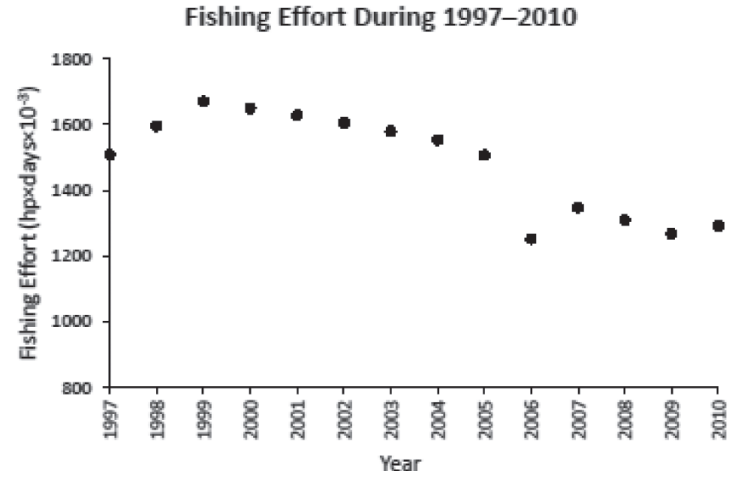

Fig. 3. The fishing effort of the Israeli trawl fleet during the years $1997-2010$

1996, where the fishing effort was between 688 to 1384 units of effort, and 1997-2010 (12531671 units) (Table 2), we see a significant increase in fishing effort, but the yield remained almost the same.

\section{DISCUSSION}

The Fox model (Fox, 1970) model was found to be adequate for describing the relationship between catch and fishing effort of the Mediterranean trawl fishery of Israel. SPARRE and VENEMA (1998) considered the Fox model to be a "holistic model" that approached the entire fishing effort as one unit and the captured biomass as an entire unit as well, without the 
need to consider the species composition or the length/age composition of each species.

As a result of the sharp increase in the beginning of the 1980's of the Israeli Mediterranean trawl fishing effort, PISANTY \& GROFIT (1991) used the Fox model to analyze the catch during the years 1963-1969 and 1980-1987. They estimated the MSY for these periods to be close to 1,500 tons using 1,154 units of effort. As a result of that study and due to fear of overfishing the local Department of Fisheries ruled to "freeze" the fleet size, allowing new vessels to join the fleet only with the cessation of activities by an existing active trawler. It should be noted that the result of the present study, that includes a larger body of data than the earlier study reached similar values that justify retaining the trawling fleet at its current level.

The use of higher fishing effort in the years 1998-2010, in order to catch the same yield as in the period of 1985-1997 (Table 1, Fig. 1) did not lead to collapse of the catch. The results of assessment by the Fox model were hence proven correct (i.e. MSY was approximately 1,400 tons); this is apparently the limit of the carrying capacity of the local marine environment for bottom trawling. It is interesting to note that, during the years 2006-2010, the fishing effort decreased to the level prevalent in the early 1990's, yet the yield remained close to the estimated MSY. This finding may be explained by the fact that the Israeli fishing grounds areas are very small (ca. $190 \mathrm{~km}$ along the Israeli coast) and are constantly enhanced by the intake of neighboring populations.

The entire trawl catch of the years 20112015 has remained similar to that of previous years (J. Shapiro, personal communication) but data on the fishing effort of this recent period are not available, which precludes us from including it in the present study.

One of the most common public claims against the trawl fishery in the Mediterranean coast of Israel is that its non-selective catch negatively influencing the catch of other fishing methods, such as trammel net, longline and purse seine. Since each fishing method utilizes different habitats and therefore exploits differ- ent species, there is very little overlap between the catch of the fishing methods (SCHEININ et al., 2014). The main species of the Israeli trawl catch (i.e. the fish species Saurida lessepsianus, Merluccius merluccius, Mullus barbatus, M. surmuletus, Upeneus moluccensis, U. pori, Nemipterus randalli, Pagellus erythrinus, the cephalopod Loligo vulgaris and the shrimps Marsupeneus japonicus, Metapenaeus monocerus and Penaeus semisulcatus (GOLANI \& BEN-TUVIA, 1995) are caught only by trawl and therefore cannot affect the abundance of species caught by other methods. However, while trawlers target mainly the species mentioned above, a small portion of the trawl catch may include young stages of larger body species such as Seriola dumerili, Scomberomorus commerson, Epinephelus aeneus and Pagrus coeruleostictus; these species usually mature and subsequently leave the trawling grounds for other habitats. The precise magnitude of the catch of these species and the proportion from their entire population and their natural survival rate are unknown, due to lack of stocks assessment and population dynamic studies in this region. Thus, it is difficult to measure the impact of trawler catch on other fishing methods.

The growing proportion of the discarded catch in the Israel trawl fishery has been noted as a result of the intensification, in the last two decades, of marine Red Sea invasive species (Edelist, 2013; Edelist et $a_{2}$ 2013b; Golani, 2010). Most of the fast growing populations of these Lessepsian migrants are small body, noncommercial species (e.g. Plotosus lineatus, four species of the family Apogonidae, three species of the genus Lagocephalus, Callionymus filamentosus, Equulites klunzingeri) .

Finally, it must be acknowledged that the collapse of Israel's inshore fisheries (Edelist et al, 2013b) is a result of a complex set of circumstances, most of which are not trawl related and some are even ex-fishery factors such as bio-invasion coupled with climate change, damming the Nile, geo-political issues such as international trade agreements and economic drivers such as rising fuel prices. While overexploitation (by any gear) may not be discounted as a 
partial reason for the inshore collapse; the lack of good data for the fleet and catch still hinders our understanding, and pinning this collapse solely on bottom trawling, which is shown here to be a relatively stable fishery, is not supported scientifically, as we have shown in this study

\section{REFERENCES}

EDELIST, D. 2013. Fishery Management and Marine Invasion in Israel. PhD. Dissertation, University of Haifa, 220 pp.

EDELIST, D., O.SONIN, D. GOLANI, G. RILOV \& E. SPANIER. 2011. Spatiotemporal patterns of catch and discards of the Israeli Mediterranean trawl fishery in the early 1990s: ecological and conservation perspectives. Sci. Mar., 75(4): 641-652.

EDELIST, D., A. SCHEININ, O. SONIN, J. SHAPIRO, P. SALAMEH, G. RILOV, Y. BENAYAHU, D. SCHULZ \& D. ZELLER. 2013a. Israel: reconstructed estimates of total fisheries removals in the Mediterranean, 1950-2010. Acta Adriatica, 45 (2): 253-264.

EDELIST, D., G. RILOV, D. GOLANI, J.T. CARLTON \& E. SPANIER. 2013B. Restructuring the sea: profound shifts in the world's most invaded marine ecosystem. Diversity and Distributions, 19: 69-77.

FOX, W.W. 1970. An exponential surplus-yield model for optimization exploited fish populations. Transaction of the American Fishery Society, 99(1): 80-88.

GOLANI, D. 2010. Colonization of the Mediterranean by Red Sea fishes via the Suez Canal - Lessepsian migration. In: Fish Invasions of the Mediterranean Sea: Change and Renewal. D. Golani \& B. Appelbaum Golani (Editors). Sofia: Pensoft. pp. 145-188.

GOLANI, D. \& A. BEN-TUVIA. 1995. Lessepsian migration and the Mediterranean fisheries of Israel. In: Conditions of the World's Aquatic Habits. Armantrout, N.B. (Editor). Proceedings of the World Fisheries Congress Theme 1. Oxford \& IBH Pub. Co. Pvt. Ltd., New Delhi., pp. 279-289.

GOTTLIEB, E. \& O.H. OREN. 1975. Saving gear experiments with trawl net in Israel waters.
General Fisheries Council for the Mediterranean - GFCM, FAO, Rome, 4: 281-287.

GROFIT, E. 1980. The artisanal coastal fishery in the eastern Mediterranean. General Fisheries Council for the Mediterranean (GFCM), FAO, Rome, GFCM/XV/80/20, 19 pp.

HORNELL, J. 1935. Report on the fisheries of Palestine. Jerusalem, London (Crown agent for the Colonies on behalf of the Government of Palestine), $106 \mathrm{pp}$.

PISANTY, S. \& E. GROFIT. 1991. Limiting effort in the Israeli trawl fishery. Fishery and Fish breeding in Israel, 24(4): 100-112 (in Hebrew with English abstract).

SCHEININ, A. 2010. The population of bottlenose dolphin (Tursiops trucatus), bottom trawl catch trends and the interaction between the two along the Mediterranean continental shelf of Israel. (in Hebrew with English Summary). PhD Thesis. University of Haifa, $172 \mathrm{pp}$.

SCHEININ, A., D. EDELIST \& O. SONIN. 2014. The fishery along the coast of Israel - past, present and perhaps also future. In: The Glory of the Sea: Stability and Change in the Aquatic Systems of Israel (in Hebrew). N. Stembler (Editor). The Israeli Association of Aquatic Sciences, pp. 223-283.

SPARRE, P. \& S.C. VENEMA. 1998. Introduction to tropical fish stock assessment. Part 1. Manual. FAO Fisheries Technical Paper. No. 306.1, Rev. 2. Rome, FAO, 407p.

VAN RJIN, E., O. GIVAN, E. GRANOT, A.VIDAN, R. PIKHOLTZ, O. FRIED \& J. BELMAKER. 2014. The catch of a trawler for the years 19762010 as reflected from its log books (in Hebrew). Ekologya ve'Sviva (Ecology and Environment), 5(1): 106-110. 


\title{
Dugoročno istraživanje ulova (1949-2010) i ribolovnog napora izraelskih koćarica u istočnom dijelu Sredozemlja
}

\author{
Daniel GOLANI*, Dor D. EDELIST, Amit LERNER, Oren SONIN i \\ Uzi MOTRO
}

*Kontakte-adresa:dani.golani@mail.huji.ac.il

\begin{abstract}
SAŽETAK
Koćarski ulov na sredozemnoj obali Izraela analiziran je s obzirom na ulov i ribolovni napor od 1949. do 2010. godine. Maksimalni održivi prinos (MSY) izračunat je primjenom Fox modela za viši?? prekomjerni ulov i utvrđeno je da iznosi 1.413 tona godišnje koristeći 1.415 jedinica napora (dani ribolova x motorna snaga podijeljena s 1000). Tijekom devet godina (1997.- 2005.) ribolovni napor premašuje vrijednost čiji maksimalni održivi prinos (MSY) iznosi u prosjeku 184,9 jedinica, dok je prinos bio sličan onome prethodnih godina. Tijekom 10 godina ulov je premašio, maksimalni održivi prinos (MSY) za prosječno $153 \pm 119$ tona. Taj rezultat je bio upotrebljen kao argument za „zamrzavanje“ lokalne kočarske flote početkom 1990-ih godina.
\end{abstract}

Ključne riječi: koće, Izrael, Sredozemlje, maksimalni održivi prinos, Fox model 
